\title{
Aluminium Primary Production Off-Gas Composition and Emissions: An Overview
}

\author{
THOR ANDERS AARHAUG ${ }^{1,2}$ and ARNE PETTER RATVIK ${ }^{1}$ \\ 1.—SINTEF Industry, Trondheim, Norway. 2.-e-mail: taarhaug@sintef.no
}

The raw gas composition from primary aluminium production depends mostly on the process technology applied and the composition of the raw materials. At steady state, a stationary condition is established among the material sources, gas production and sinks: the gas treatment centre and escaping gases. Only a few papers discuss the off-gas composition itself; most papers deal with the gas composition from laboratory-scale experiments performed under inert conditions. In this article, an overview of the literature describing gas production from aluminium electrolysis is given. Effects of temperature and chemical equilibrium on the stationary condition are also discussed. The typical chemical composition of the raw materials is presented to evaluate their input into the gas composition, especially with respect to their impurity levels.

\section{PROCESS OVERVIEW}

\section{The Smelting Process}

Aluminium (Al) is produced by electrochemical reduction of alumina $\left(\mathrm{Al}_{2} \mathrm{O}_{3}\right)$ dissolved at about $950^{\circ} \mathrm{C}$ in a molten salt based on cryolite $\left(\mathrm{Na}_{3} \mathrm{AlF}_{6}\right)$ with aluminium fluoride $\left(\mathrm{AlF}_{3}\right)$ and calcium fluoride $\left(\mathrm{CaF}_{2}\right)$ to reach an $\mathrm{NaF}$ (sodium fluoride) to $\mathrm{AlF}_{3}$ molar ratio of about 2.2. Direct current (DC) is provided as the energy required by the reduction reaction as well as maintaining the cryolite bath temperature through resistive heating and compensate for heat losses. Carbon (C) anodes are consumed by the anode reaction as a reducing agent, forming mainly carbon dioxide $\left(\mathrm{CO}_{2}\right)$ besides some carbon monoxide (CO). Graphite is most commonly used as current conductor to the cathode in modern electrolysis cells (the graphite is commonly denoted as the cathode although, in principle, the aluminium pad on top of the graphite is the cathode). The net reaction is:

$$
\frac{1}{2} \mathrm{Al}_{2} \mathrm{O}_{3}(\mathrm{~s})+\frac{3}{4} \mathrm{C}(\mathrm{s})=\mathrm{Al}(\mathrm{l})+\frac{3}{4} \mathrm{CO}_{2}(\mathrm{~g})
$$

The produced metal has a higher density than the electrolyte and is regularly tapped (siphoned) from the aluminium pad over the bottom of the cell. The anodes are covered by anode cover material (ACM) to minimise the heat loss from the process as well as prevent air and $\mathrm{CO}_{2}$ burns of the anodes, which increase the carbon consumption.

Whereas open electrolysis cells were historically used, modern technology makes use of a superstructure to contain the gases and dust produced during smelting. Large fans are used to extract these gases along with air from the draught, the draught serving to cool the off-gas as well as the superstructure.

\section{Gas Treatment Centre}

Due to the negative environmental impact of fluoride and sulfur emissions, the off-gases are treated before being emitted to the environment. In the early 1970 s, scrubbing technology, making use of primary alumina to clean the off-gas, was established. By exposing the off-gas to alumina and retaining fine particulates using bag filters, emissions were drastically reduced. The alumina (secondary alumina) from the gas treatment centre (GTC) is then fed to the reduction cells.

The scrubbing efficiency is dependent on many factors, but normal operation of the GTC allows for scrubbing efficiencies $>99 \%$ in the case of hydrogen fluoride (HF) and fluoride particulates. The high efficiency in recovery of fluorides also has an economic impact, as less $\mathrm{AlF}_{3}$ must be added to maintain the $\mathrm{NaF} / \mathrm{AlF}_{3}$ bath ratio. 


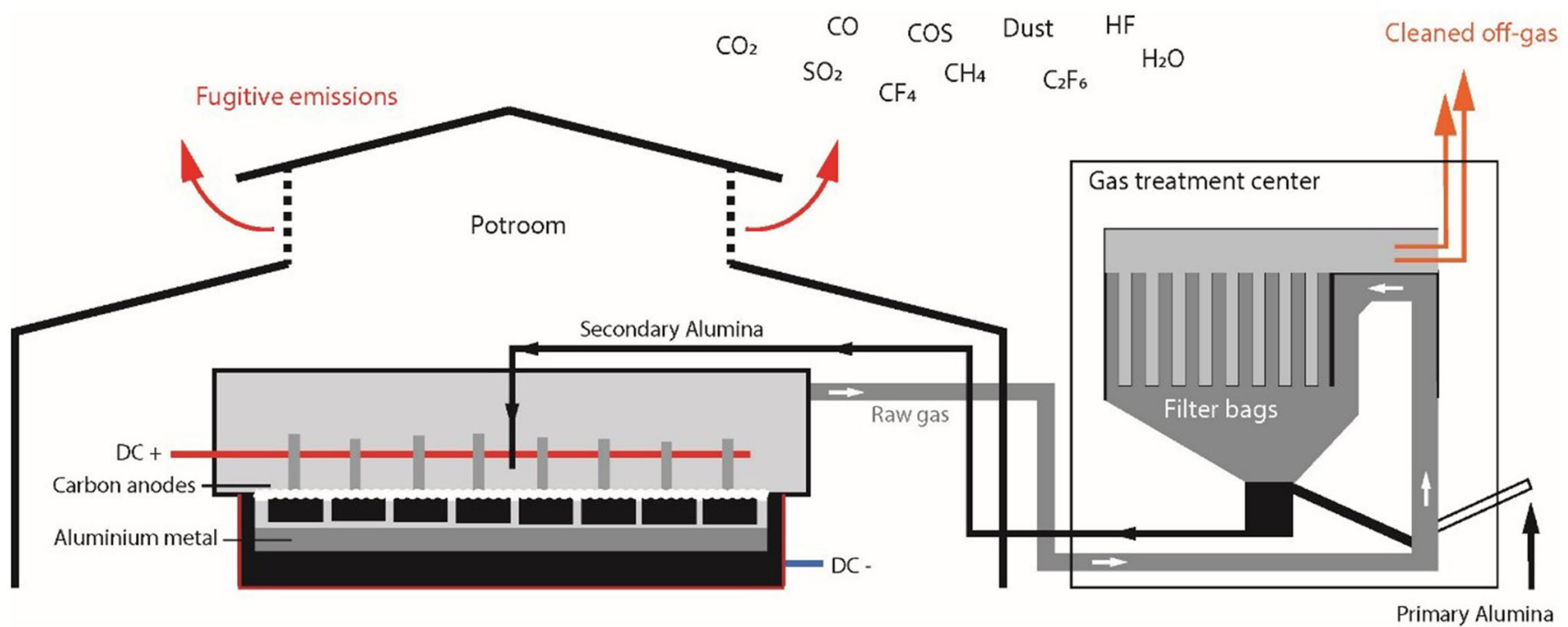

Fig. 1. Schematic of the material flow among the smelting process, gas treatment centre and emissions.

The scrubbing efficiency for other gas species than $\mathrm{HF}$ is less efficient. Permanent gases, such as $\mathrm{CO}, \mathrm{CO}_{2}$ and PFCs, pass readily through the filter. Sulfurous gases such as COS and $\mathrm{SO}_{2}$ are partially retained by the scrubber and returned to the cells. In the case of $\mathrm{SO}_{2}$, the limiting scrubbing efficiency is a result of the competition with the stronger adsorbing $\mathrm{HF}$ over $\mathrm{SO}_{2}$ on alumina. ${ }^{1}$ As the off-gas is the only sink for sulfur, all sulfur eventually ends up as emissions.

Where legislation restricts $\mathrm{SO}_{2}$ emissions, the dry scrubber is accompanied by a wet scrubber. The wet scrubber makes use of either seawater or a caustic solution to capture $\mathrm{SO}_{2}$ as sulphate.

\section{Impurity Cycling}

Whereas the introduction of off-gas scrubbing led to a positive environmental effect as well as improved economics, there are also some negative effects. By introducing filters, virtually all particulate matter is trapped and returned to the process with the secondary alumina. Impurities trapped in the gas treatment centre will therefore accumulate in the process unless they are provided another sink. Fugitive emissions from the potroom, resulting from incomplete evacuation of the off-gases from the superstructure and open lids during anode changes, are now the major emission routes for gases and particulates otherwise captured by the dry scrubber. Management measures to reduce fluoride emissions in plants have been proposed. ${ }^{2}$ The other major sink is the produced aluminium metal. The interaction among the smelting process, gas cleaning and emissions is illustrated in Fig. 1.

One example of an impurity with a negative impact is phosphorous. Phosphorous has several oxidation numbers and thus negatively affects the current efficiency of the process. Phosphorous has low metal solubility and few gaseous species. Other examples include metals, where metals more noble than aluminium mostly report to the metal whereas less noble metals predominate in the electrolyte. Often a ratio of 10:1 between the metal and bath is reported for the more noble impurities, while a reverse ratio of 1:10 is reported for the less noble impurities.

\section{The Fluoride Cycle}

Fluoride is an essential part of the process as sufficient alumina dissolution is only possible in fluoride-based molten salt systems. The major losses of fluorides are due to fugitive emissions in the form of particulates and free or adsorbed gases. The GTC effectively captures $>99 \%$ of the fluorides in the raw gas and reintroduces the fluorides to the electrolysis bath. At operating temperature, $\mathrm{NaAlF}_{4}$ (sodium tetrafluoroaluminate) is the main fluoride compound evaporating from the molten electrolyte. The off-gas temperature drops rapidly as it enters the superstructure and meets the draught, causing the metastable $\mathrm{NaAlF}_{4}$ to be quenched. In addition, $\mathrm{NaAlF}_{4}$ disproportionates to form chiolite $\left(\mathrm{Na}_{5} \mathrm{Al}_{3} \mathrm{~F}_{14}\right)$ and $\mathrm{AlF}_{3}$. As the off-gas reaches the GTC, HF is the only gaseous fluoride species apart from minor amounts of perfluorocarbon species formed during anode effects or in alumina-depleted spots under the anodes.

\section{The Sulfur Cycle}

Sulfur is introduced to the process mainly as an impurity in the anode carbon. Carbonyl sulphide (COS) is the main sulfur gas species formed during the oxidation of sulfur bound with carbon. COS reacts with oxygen in the air to form sulfur dioxide $\left(\mathrm{SO}_{2}\right)$, which is the major sulfurous gas species found in the off-gas reaching the GTC. Not many data have been published on retaining sulfur in the GTC, but both $\mathrm{SO}_{2}$ and COS exhibit a significant 
concentration difference over the GTC. The observed reduction in COS may be caused by catalytic hydrolysis in contact with alumina in the GTC. ${ }^{3}$ Secondary alumina with adsorbed sulfur gases and sulphates is returned to the electrolysis bath. ${ }^{4-6}$ Upon dissolution of alumina, most of the sulfur is rapidly re-released to the gas phase, although mechanisms have been reported for sulphite and sulphate formation. ${ }^{7}$ The short residence time in the cell increases the gas release from the bath and potentially entrainment of bath compounds and particulates. Due to the lower GTC scrubbing efficiency for sulfur, gas emission from the GTC are the major contributor to sulfur emissions unless a wet scrubber is installed.

\section{Off-Gas Composition}

Very little information has been published regarding the full composition of the off-gas from primary aluminium production. A major obstacle to characterization is the detrimental effect of $\mathrm{HF}$ to multicomponent gas analysers. Therefore, most characterization has been performed downstream the GTC.

Whereas quite a few gas constituents are known to pass unhindered through the GTC (e.g., $\mathrm{CO}_{2}, \mathrm{CO}$, $\mathrm{PFC}, \mathrm{N}_{2}$ ), others show various degrees of retention (e.g., $\mathrm{HF}, \mathrm{SO}_{2}, \mathrm{COS}$ ). The retention will vary with technology, raw gas temperature and humidity and therefore makes projection of off-gas composition from the cleaned gas side difficult.

The variations in dilution by draught under the cell hoods are one contributor to variations in the off-gas concentrations. The main constituents of air $\left(\mathrm{N}_{2}, \mathrm{O}_{2}, \mathrm{Ar}, \mathrm{H}_{2} \mathrm{O}\right)$ co-vary and dilute the process gases. However, several mechanisms may affect this ratio, such as CO burn and oxidation of COS. Nevertheless, a generalization of the composition has been attempted in Table I, based on unpublished results from the authors. Some reasons for the drop in $\mathrm{SO}_{2}$ across the GTC are believed to be caused by adsorption of $\mathrm{SO}_{2}$ on alumina as well as partial conversion to sulphate or $\mathrm{SO}_{4}{ }^{2-}$ or operation of the scrubber at an elevated new ore feed rate.

Characterizations of dust loading and fluoride and sulfur content are performed by the smelters on a regular basis. Typical dust loads in the ducts have

Table I. Generalized gas composition relative to CO. Sulfur losses have not been quantified in the literature but are indicated in the table with $a<$

\begin{tabular}{lcc}
\hline Gas & Raw gas & After GTC \\
\cline { 2 - 3 } $\mathrm{CO}$ & 1 & 1 \\
$\mathrm{CO}_{2}$ & 10 & 10 \\
$\mathrm{HF}$ & 0.07 & 0.001 \\
$\mathrm{SO}_{2}$ & 0.1 & $<0.1$ \\
$\mathrm{COS}$ & 0.01 & $<0.01$ \\
\hline
\end{tabular}

been reported in the range of $0.3 \mathrm{~g}$ dust per $\mathrm{kg}$ exhaust gas by Fleer. ${ }^{8}$ For the reported exhaust flow of $6100 \mathrm{Nm}^{3} / \mathrm{h}$ per cell (190 kA cells), considering variations in the suction and size of cells between different plants, it is reasonable to assume that the particulate load is in the range of $1-3 \mathrm{~kg} / \mathrm{h}$ per cell $\left(1 \mathrm{Nm}^{3} / \mathrm{h}=1.295 \mathrm{~kg} / \mathrm{h}\right)$, depending on the suction rate and particle size distribution of the secondary alumina. Based on analyses of the impurities in the off-gas and secondary alumina, ${ }^{9}$ it is shown that the finer fractions consist mainly of condensed bath particles whereas the impurities are generally found in the lower micron size fractions together with the secondary alumina fines.

\section{Technology Prospects}

The ultimate goal of industrial production of primary aluminium is zero emissions, no environmental impact and no waste of energy or materials. Despite significant improvements in these issues over the last decades, the industry is expected to face even stricter regulations in the future. To answer this challenge, both new operation standards and improved systems will be required.

Exact knowledge of fundamental process mechanisms is a prerequisite to push the limits, requiring dedicated research and innovations and willingness to pursue new ideas, especially for waste and emissions not readily handled with today's technology. This article gives an overview of the existing knowledge and presents future challenges.

\section{Environmental Aspect}

Over the years, the aluminium industry has managed to reduce emissions from the production steps to a significant degree. The most noticeable progress was obtained by the introduction of dry scrubbers as most of the particulates and fluorides in the off-gas emissions are captured by dry scrubbers. Since most of the sulfur gases pass through the dry scrubber, many plants are still emitting significant amounts of sulfur dioxide $\left(\mathrm{SO}_{2}\right)$ and carbonyl sulfide (COS) to the atmosphere. In countries with stricter regulations on sulfur emissions, wet scrubber systems are implemented. Seawater scrubbing is the preferred method for plants located at the coast, while caustic solutions are used elsewhere. If the electrolyte is depleted in alumina, potent greenhouse perfluorocarbon (PFC) gases are formed. Although the decrease in the number of anode effects has reduced the formation and release of PFCs, the high greenhouse gas (GHG) potential in the range of 5000-10,000 in a 100-year perspective can cause even small emissions to contribute to the global warming.

As anodes are replaced every 3-4 weeks, furnace covers must be removed regularly. Due to the heat flux and the transport of anodes in open air, diffuse emissions are significant, from both the removed anodes and the pot with open covers, including the 
emissions during crust cleaning of the anode cavity before setting new anodes. The distribution of particulates from different pot sources, such as alumina, cover material and bath fumes, collected at different sites in aluminium plants have been reported. ${ }^{10}$ To reduce the emissions, some plants use booster suction during anode change and/or place pulled anodes in designated collecting systems with hooding during cooling.

\section{Product Quality}

Many of today's emissions are a consequence of the raw materials, e.g., impurities in the alumina $\left(\mathrm{Al}_{2} \mathrm{O}_{3}\right)$ and aluminium fluoride $\left(\mathrm{AlF}_{3}\right)$ feed, and heavy metals and sulfur present in the carbon anodes. Other emissions are a consequence of the process, e.g., fluoride emissions, or secondary reactions taking place inside the cell or in the gas duct. With efficient dry scrubbing, using the smelter grade alumina (SGA) as fluoride adsorbent before feeding the alumina to the cells, most raw gas elements in the form of particulates are returned to the cells, eventually leaving the metal and to some extent surplus electrolyte as the major sink for impurities.

Presently, there are no indications that the raw materials will be of higher purity in the future. Especially the trend within coke for carbon anodes is negative, as the availability of good quality cokes is not expected to increase at the same rate as the aluminium production. This will force the anode manufacturers and aluminium producers to accept lower quality cokes with higher impurity levels. Also, the increased production of sour oil adds to this picture, while the recent growth in shale oil, which contains few of the heavier fractions that end up as anode coke. Considering that the current growth in consumption of fossil fuels is not sustainable, the future availability may be even worse. This may require additional actions at the plants to handle or remove impurities.

\section{Energy Recovery}

Today's most energy-efficient cells of operate at $13-14 \mathrm{kWh} / \mathrm{kg}$, which is about twice the theoretical energy required to produce aluminium. ${ }^{11}$ About half of the energy input is dissipated as heat, mostly to the cell hooding (superstructure) where the current practice is to cool the off-gas by allowing a draught to enter the cell. As a consequence, the off-gas system has to pull about 100 times the gas amount produced in the cell reaction. Since the power used by the fans to manage good off-gas suction, and the energy input to the anode production is not reported in the $\mathrm{kWh} / \mathrm{kg}$ aluminium, the total energy consumption considering the whole plant operation is higher. In the future, it is expected that producers will reduce the draught and install heat exchangers in the off-gas system, opening up for heat recovery and/or power production as well as carbon dioxide
$\left(\mathrm{CO}_{2}\right)$ capture. Some minor efforts have started, mostly looking at heat exchangers motivated by reducing the off-gas temperature to improve the dry scrubbing. ${ }^{12-14}$

\section{IMPURITY SOURCES}

\section{Impurities in Aluminium Production}

Understanding and controlling emissions from the cells are important, both due to environmental regulations and as basis for counteractive actions from lower quality raw materials causing higher emissions. It is uncertain if the rapid growth in the global aluminium production will increase the impurity level of raw materials, but it is likely that it will not decrease. Focus here will be on the most significant impurities in the emissions, those with impact upon the work environment and/or surrounding areas.

The two main sources for impurities in aluminium production are from the alumina and carbon anodes. In addition, aluminium fluoride and contamination from production equipment contribute. Some non-metallic elements form gaseous species, which may or may not be captured in the gas treatment centre (GTC). Evaporation from the bath and bath entrainment with the off-gas are the other main sources for emissions. Most of the captured impurity elements in the GTC will accumulate in the bath and eventually end up in the metal or surplus bath. In addition, polyvalent impurities may contribute to some loss in current efficiency.

\section{Anodes}

The main emission from aluminium production is $\mathrm{CO}_{2}$ from the consumption of the carbon anodes. If the contribution from sulfur in the anodes is omitted, the theoretical carbon consumption is $333.3 \mathrm{~kg}$ per tonne of $\mathrm{Al}$ produced, equivalent to $1222.2 \mathrm{~kg}$ of $\mathrm{CO}_{2}$ per tonne $\mathrm{Al}$. In reality, the carbon consumption exceeds $400 \mathrm{~kg}$ because of secondary reactions, i.e., air burn (poor coverage of anodes) and the Boudouard reaction $\left(\mathrm{CO}_{2}\right.$ burn), resulting in $\mathrm{CO}_{2}$ emissions closer to $1500 \mathrm{~kg} /$ tonne $\mathrm{Al}$.

All cokes used in the production of anodes for aluminium electrolysis contain sulfur. A certain content of sulfur in anode cokes is considered beneficial for the anode performance, based on better results in the ISO 12981-1:2000 $\mathrm{CO}_{2}$ reactivity test $\left(\mathrm{CO}_{2}\right.$ burn $)$, resulting in most anodes being produced with a sulfur content between $1.5 \mathrm{wt} \%$ and $2 \mathrm{wt} . \%$ sulfur, equivalent to $12-16 \mathrm{~kg} \mathrm{SO}_{2}$ released per tonne of aluminium produced. Different cokes are usually blended to obtain the desired sulfur content. The forecast for anode cokes of good quality to meet the growth in the aluminium industry is, however, bleak, so this sulfur content may increase. 
As most impurities in anode cokes correlate with sulfur, other impurities are also expected to increase unless the coke precursors are purified and/or desulfurized prior to coking (e.g., see Lindsay ${ }^{15}$ ). Sulfur is mainly released from the anodes as COS, which rapidly reacts to $\mathrm{SO}_{2}$ in contact with air. Impurities are also introduced to the anodes through recycled butts. These are mainly bath components already present in the cell, but may also contain minor metallic impurities from the butts cleaning process.

As basis for the discussions, an approximate overview of impurities in cokes used in carbon anode production is shown in Table II. In addition, impurities present in the coal tar pitch will contribute to the impurities in the anodes. ${ }^{16-18}$ Although many of the heavy metals can be found in the off-gas, these are captured in the GTC and returned to the cell where they eventually end up in the aluminium metal. Vanadium is considered a catalyst for air burn (ISO 12982-1:2000) and, as such, contributes to excess carbon consumption, although this is debated. ${ }^{19}$ The alkali and alkali earth elements accumulate in the bath, resulting in the need to periodically tap surplus bath from the cells to maintain the desired composition $\left(\mathrm{NaF} / \mathrm{AlF}_{3}\right.$ ratio). Since both $\mathrm{Na}$ and, to some extent, $\mathrm{Ca}$ are introduced to the anodes through recycling of butts, these elements are higher in the baked anodes than indicated in Table I, Na typically $>200 \mathrm{ppm}$. Poorly cleaned butts are blamed for both increased dusting and carbon gasification. Carbon particles from the anodes are also entrained in the off-gas, eventually resulting in increased carbon dusting in the bath as they are captured in the GTC and recycled to the cells with the alumina.

The replacement of consumed carbon anodes is the main source of fugitive emissions, related to the open cell covers, the grabbing or cleaning of the

Table II. Typical elements in anode cokes (ppm by weight unless otherwise stated), extracted from several sources ${ }^{18,20-24}$

\begin{tabular}{|c|c|c|c|c|c|}
\hline Element & Low & High & Element & Low & High \\
\hline $\mathrm{Al}$ & 20 & 250 & $\mathrm{Na}$ & 20 & 140 \\
\hline B & 1 & 15 & $\mathrm{Ni}$ & 50 & 500 \\
\hline $\mathrm{Ca}$ & 20 & 150 & $\mathrm{P}$ & 5 & 30 \\
\hline $\mathrm{Cr}$ & 1 & 50 & $\mathrm{~Pb}$ & 3 & 10 \\
\hline $\mathrm{Cu}$ & 20 & 50 & S, wt. $\%$ & 0.5 & 5 \\
\hline $\mathrm{Fe}$ & 50 & 350 & $\mathrm{Si}$ & 20 & 250 \\
\hline $\mathrm{Ga}$ & 14 & & $\mathrm{Ti}$ & 2 & 50 \\
\hline H, wt.\% & 0.1 & 0.15 & $\mathrm{~V}$ & 30 & 500 \\
\hline $\mathrm{K}$ & 10 & 20 & $\mathrm{Zn}$ & 2 & 150 \\
\hline $\mathrm{Mg}$ & 50 & 200 & & & \\
\hline $\mathrm{Mn}$ & 4 & 100 & Ash, wt. $\%$ & 0.05 & 0.4 \\
\hline Mo & 10 & 20 & Volatiles, wt.\% & 0.1 & 0.8 \\
\hline $\mathrm{N}$, wt. $\%$ & 0.2 & 0.4 & Moisture, wt.\% & 0.1 & 0.4 \\
\hline
\end{tabular}

anode cavity in the cell and emissions from the removed bath and hot anodes.

\section{Smelter-Grade Alumina (SGA)}

Known bauxite sources for alumina production are abundant and it is not likely that the industry will see major changes in the alumina quality, although some sources of lower quality alumina are being used in some countries. A concern regarding alumina is if countries with major raw material sources introduce processing or export restrictions, forcing lower grade ores to be processed or higher throughput in existing refineries. Besides the contributions from impurities in the primary alumina to gas emissions, other inherent effects are the accumulation of surplus bath due to the sodium content in the alumina and the dusting caused by the finer alumina fractions. Loss on ignition (LOI) for primary SGAs are typically up to $1 \mathrm{wt} . \%$, mostly due to bound hydroxides or oxyhydroxides. The alumina, containing hydroxy groups $\left(\mathrm{OH}^{-}\right)$and adsorbed moisture, is the major source of hydrogen contributing to the formation of $\mathrm{HF}$ and emissions from the cells. In addition, the $\mathrm{HF}$ captured by the gas treatment (e.g., as $\mathrm{AlF}_{3} \cdot x \mathrm{H}_{2} \mathrm{O}$ on reacted alumina), which is fed to the cells, also contributes. ${ }^{25}$

The most common impurities in primary alumina, cryolite and aluminium fluoride are shown in Table III. Since impurities in aluminium fluoride are quite similar to impurities in alumina and contribute to emissions, $\mathrm{AlF}_{3}$ is included in Table III for completeness. The contributions from bath additions during start-up of new or relined cells are less important. Since solid impurities in the off-gas are captured in the GTC, the real impurity level of the alumina (the secondary alumina) added to the cells is significantly higher than in the primary smeltergrade alumina (SGA). ${ }^{26-28}$

Several industrial studies show that alumina additions are followed by a rapid increase in HF formation. ${ }^{34,35}$ Hyland, Patterson and Welch ${ }^{36}$ showed that the smelter-grade alumina is the major cause for HF generation in the cell, mostly due to adsorbed moisture and hydroxy groups in the unconverted gibbsite. Proposed reactions are:

$$
\begin{aligned}
2 \mathrm{AlF}_{3}(\text { g or diss }) & +3 \mathrm{H}_{2} \mathrm{O}(\mathrm{g}) \\
= & 6 \mathrm{HF}(\mathrm{g})+\mathrm{Al}_{2} \mathrm{O}_{3}(\mathrm{~s} \text { or diss }) \\
& \\
3 \mathrm{NaAlF}_{4}(\mathrm{~g})+3 \mathrm{H}_{2} \mathrm{O}(\mathrm{g})= & 6 \mathrm{HF}(\mathrm{g})+\mathrm{Al}_{2} \mathrm{O}_{3}(\mathrm{~s}) \\
& +\mathrm{Na}_{3} \mathrm{AlF}_{6}(\mathrm{~s})
\end{aligned}
$$

Thermodynamically, the first one is most likely, although the reactions taking place may differ because of other oxygen-containing ions in the bath. $^{37,38}$ LOI $\left(20-300^{\circ} \mathrm{C}\right)$ values for secondary alumina were found to be in the $0.6-2.0 \%$ range, depending on humidity. ${ }^{36}$ In addition, some residual oxyhydroxides bound in other transition aluminas 
Table III. Typical impurities in primary alumina, cryolite and aluminium fluoride. $\mathrm{Al}_{2} \mathrm{O}_{3}$ in $\mathrm{AlF}_{3}$ is included for comparison. Extracted from several sources, including ${ }^{29-33}$

\begin{tabular}{|c|c|c|c|}
\hline Impurity & $\mathrm{Al}_{2} \mathrm{O}_{3}$ (wt.\%) & $\mathrm{Na}_{3} \mathrm{AlF}_{6}$ (wt.\%) & $\mathrm{AlF}_{3}$ (wt.\%) \\
\hline $\mathrm{Al}_{2} \mathrm{O}_{3}$, wt. $\%$ & & & 6-9 \\
\hline $\mathrm{SiO}_{2}$ & $0.007-0.02$ & $0.12-0.13$ & $0.001-0.1$ \\
\hline $\mathrm{Fe}_{2} \mathrm{O}_{3}$ & $0.008-0.022$ & $0.04-0.11$ & $0.005-0.05$ \\
\hline $\mathrm{TiO}_{2}$ & $0.002-0.008$ & $0-0.001$ & $0.0008-0.0012$ \\
\hline $\mathrm{CaO}$ & $0.003-0.035$ & $0.06-0.1$ & $0.001-0.1$ \\
\hline $\mathrm{ZnO}$ & $0.001-0.011$ & & \\
\hline $\mathrm{V}_{2} \mathrm{O}_{5}$ & $0.0012-0.004$ & $0.001-0.005$ & $0.0002-0.0003$ \\
\hline $\mathrm{P}_{2} \mathrm{O}_{5}$ & $0.0004-0.0011$ & $0.015-0.02$ & $0.001-0.02$ \\
\hline $\mathrm{Cr}_{2} \mathrm{O}_{3}$ & 0.002 & & \\
\hline $\mathrm{Ga}_{2} \mathrm{O}_{3}$ & $0.007-0.008$ & & \\
\hline $\mathrm{Na}_{2} \mathrm{O}$ & $0.3-0.45$ & $0.10-0.15$ & $0.05-0.25$ \\
\hline $\mathrm{Li}_{2} \mathrm{O}$ & $0-0.001$ & & \\
\hline $\mathrm{K}_{2} \mathrm{O}$ & $0.01-0.08$ & & \\
\hline $\mathrm{H}_{2} \mathrm{O}$ & & $0.17-0.3$ & $0.2-0.3$ \\
\hline $\mathrm{SO}_{4}$ & & $0.54-0.69$ & $0.9-1.5$ \\
\hline LOI, \% & $0.4-1$ & & $<1$ \\
\hline
\end{tabular}

will be released at higher temperatures, which contribute to delayed formation of HF in the cell. Another observation in the laboratory experiments was that apparently no HF was generated when the current was shut off. In addition, hydrated alumina showed no difference in average $\mathrm{HF}$ emissions compared to primary alumina, indicating that most HF-forming reactions take place in the bath. This contradicts the findings of Sommerseth et al., ${ }^{37}$ showing that both moisture and hydroxy groups contribute to HF formation when added to a standard electrolyte composition in a laboratory cell without applying current.

Perander et al. ${ }^{39}$ studied the impact of fines in SGA. Undercalcined SGA causes increased dusting, loss of bath, additional HF formation and possibly bath instability. They showed that the gibbsite is converted to $\gamma$-alumina in the temperature range $270-300^{\circ} \mathrm{C}$ according to:

$$
2 * \mathrm{Al}(\mathrm{OH})_{3}=\mathrm{Al}_{2} \mathrm{O}_{3}(\mathrm{~s})+2 \mathrm{H}_{2} \mathrm{O}(\mathrm{g})
$$

\section{Anode Cover Material}

In the electrolysis cell, the carbon anodes are covered to reduce air and $\mathrm{CO}_{2}$ burn. The cover also acts as thermal insulation at the top of the anodes. The anode cover material is generally comprised of bath and secondary alumina. The use of a bath in the cover may also contribute to controlling the bath level in the cell. ${ }^{40}$ In this case, impurities that report mainly to the bath (e.g., phosphorous) are therefore recycled. The anode cover material may vary in particle size distribution because of the various types of materials used. Size and impurity distribution in secondary alumina and anode cover materials have been reported by Aarhaug and Ratvik. $^{41}$

\section{INSTRUMENTATION FOR GAS ANALYSIS}

A wide range of analytical techniques for characterization of the off-gas exists. Some of the more commonly used instruments are presented.

\section{Tuneable Diode Laser Spectroscopy (TDLAS)}

TDLAS is an infrared absorption technique that makes use of a diode laser as a narrow-bandwidth light source. Typical implementation of TDLAS has been applying lasers in the near infrared range (NIR, 700-2500 nm), but laser diode developments have made the mid-infrared (MIR, 2500-25000 nm) available. TDLAS has potentially high specificity, but requires selection of a band with no or limited interference.

TDLAS sensitivity depends on analyte-specific absorptivity and light path length. In extractive configurations, multi-pass configurations are used to obtain the desired sensitivity. ${ }^{42}$ The trade-off for sensitivity is often a loss in dynamics due to the increased volume of the measurement cell. ${ }^{43}$

For in-line configurations, the across-duct installation diameter would normally dictate the quantification limit. References to multi-pass configurations for in-line monitoring have not been found. TDLAS has also seen extractive applications. ${ }^{44}$ Additionally, long light paths established in cavity ring-down spectroscopy (CRDS) and optical feedback cavity enhanced spectroscopy can be utilized for extreme analyte sensitivity.

Although most implementations of TDLAS are limited to a single analyte, it is possible to tune the diode laser so that more analytes are covered. 


\section{Fourier-Transform Infrared Spectroscopy (FTIR)}

FTIR spectroscopy is a well-established technique where a polychromatic light source is applied typically over the mid-infrared range. A Michelson interferometer is used to convert the data collected from time to frequency domain. FTIR is a very versatile technique that covers many relevant analytes. ${ }^{45}$ Using multivariate regression, such as partial least squares (PLS), robust calibration models can be established.

Permanent installations of FTIR instrumentation for in-line measurement in the aluminium industry have not been documented. FTIR instrumentation is expensive (unless the application is used for many analytes) and has high maintenance requirements (frequent collection of background spectra in inert gas). Establishment of robust calibration models is also a requirement to limit interference from water, $\mathrm{CO}_{2}$ and $\mathrm{SO}_{2}$.

\section{Gas Chromatography}

By application of chromatographic separation of analytes through a column, a non-specific detector, such as a thermal conductivity detector (TCD), can be applied for gas analyte qualification and quantification. The limitations of TCD are the sensitivity (typically ppm range) and the need for various columns and carrier gases dependent on the analyte.

A range of detectors is available for gas chromatography. In this context, mass spectrometry detectors (MCDs) are worth mentioning. In addition to the analyte separation given by the chromatographic column, the mass spectrometer will further resolve gas species with near-identical elution times.

Traditionally, gas chromatographic separation is a slow process with elution times up to $30 \mathrm{~min}$. With modern, fast columns, separation times can be as low as $2-3 \mathrm{~min}$. An inherent problem with column separation is a requirement of a "clean" gas: particulates and condensation could potentially clog the capillary column.

\section{Mass Spectrometry}

The availability of commercially process mass spectrometers is increasing. Traditionally, electron impact (EI) ionization has been the dominant technique, but also ion molecule reaction (IMR) and selected ion-flow tube (SIFT) ionization techniques have become available.

Omitting the gas chromatographic separation, the mass spectrometric sensitivity can be significantly improved. For EI, deconvolution of overlapping spectral information can be difficult. For primary aluminium production off-gas, mass to charge line 28 sees contributions from $\mathrm{N}_{2}, \mathrm{CO}, \mathrm{CO}_{2}$ in a way that makes it difficult to discern $\mathrm{N}_{2}$ from $\mathrm{CO}$, even with multivariate calibration. This is, however, not a problem for IMR-MS where ionization of $\mathrm{N}_{2}$ can be avoided.

\section{Differential Optical Absorption Spectroscopy (DOAS)}

DOAS was established as a technique in order to monitor atmospheric gas species. A differential absorption cross section $\left(\mathrm{cm}^{2}\right.$ molecule $\left.{ }^{-1}\right)$ can be calculated by division of the cross section itself with a smoothed fit. In this way, the effect of Raleigh and Mie scattering can be eliminated. Also, the requirement for establishing the incident light intensity is eliminated. Although the listed benefits are normally ascribed to open path configurations, there are commercial alternatives of DOAS instrumentation for duct installations. DOAS has applications in UV, VIS and IR.

An overview of the components detectable by the different instrumental methods is provided in Table IV.

\section{OFF-GAS COMPOSITION}

\section{Introduction}

The gases originating from the reduction process are evacuated from the reduction cells by suction and diluted by draught. The extent of dilution depends on cell design as well as fan power consumption (draught and pressure loss in the off-gas system), most often dictated by the conditions required to reach an acceptable raw gas

Table IV. Overview of analytes and techniques

\begin{tabular}{|c|c|c|c|c|c|}
\hline Analyte & FTIR & TDLAS & GC-TCD & GC-MS & DOAS \\
\hline $\mathrm{N}_{2}$ & & & $X$ & $X$ & \\
\hline $\mathrm{O}_{2}$ & & $\mathrm{X}$ & $\mathrm{X}$ & $\mathrm{X}$ & $\mathrm{X}$ \\
\hline $\mathrm{Ar}$ & & & $\mathrm{X}$ & $\mathrm{X}$ & \\
\hline $\mathrm{H}_{2} \mathrm{O}$ & $\mathrm{X}$ & $\mathrm{X}$ & $\mathrm{X}$ & $\mathrm{X}$ & $\mathrm{X}$ \\
\hline $\mathrm{CO}_{2}$ & $\mathrm{X}$ & $\mathrm{X}$ & $\mathrm{X}$ & $\mathrm{X}$ & $\mathrm{X}$ \\
\hline $\mathrm{CO}$ & $\mathrm{X}$ & $\mathrm{X}$ & $\mathrm{X}$ & $\mathrm{X}$ & $\mathrm{X}$ \\
\hline $\mathrm{HF}$ & $\mathrm{X}$ & $\mathrm{X}$ & & $\mathrm{X}$ & $\mathrm{X}$ \\
\hline $\mathrm{SO}_{2}$ & X & $\mathrm{X}$ & $\mathrm{X}$ & $X$ & $X$ \\
\hline COS & $\mathrm{X}$ & $\mathrm{X}$ & $\mathrm{X}$ & $\mathrm{X}$ & $\mathrm{X}$ \\
\hline $\mathrm{CF}_{4}$ & $\mathrm{X}$ & $\mathrm{X}$ & $\mathrm{X}$ & $\mathrm{X}$ & $\mathrm{X}$ \\
\hline $\mathrm{C}_{2} \mathrm{~F}_{6}$ & $\mathrm{X}$ & $\mathrm{X}$ & $\mathrm{X}$ & $\mathrm{X}$ & $\mathrm{X}$ \\
\hline $\mathrm{C}_{3} \mathrm{~F}_{8}$ & $\mathrm{X}$ & $\mathrm{X}$ & $\mathrm{X}^{\mathrm{a}}$ & $\mathrm{X}$ & $\mathrm{X}$ \\
\hline $\mathrm{COF}_{2}$ & $\mathrm{X}$ & $\mathrm{X}$ & & $\mathrm{X}$ & $\mathrm{X}$ \\
\hline $\mathrm{SiF}_{4}$ & $\mathrm{X}$ & $\mathrm{X}$ & & $\mathrm{X}$ & $\mathrm{X}$ \\
\hline $\mathrm{HCl}$ & X & X & $\mathrm{X}$ & $\mathrm{X}$ & $\mathrm{X}$ \\
\hline $\mathrm{H}_{2} \mathrm{SO}_{4}$ & $\mathrm{X}$ & $\mathrm{X}$ & $\mathrm{X}^{\mathrm{a}}$ & $\mathrm{X}$ & $\mathrm{X}$ \\
\hline $\mathrm{CH}_{4}$ & $\mathrm{X}$ & $\mathrm{X}$ & $\mathrm{X}$ & $\mathrm{X}$ & $\mathrm{X}$ \\
\hline $\mathrm{CS}_{2}$ & $X$ & $\mathrm{X}$ & $X$ & $X$ & $\mathrm{X}$ \\
\hline $\mathrm{H}_{2} \mathrm{~S}$ & $\mathrm{X}^{\mathrm{a}}$ & $\mathrm{X}^{\mathrm{a}}$ & $\mathrm{X}$ & $\mathrm{X}$ & $\mathrm{X}^{\mathrm{a}}$ \\
\hline $\mathrm{NO}_{2}$ & $\mathrm{X}$ & $\mathrm{X}$ & $\mathrm{X}$ & $\mathrm{X}$ & $\mathrm{X}$ \\
\hline $\mathrm{NO}$ & $\mathrm{X}$ & $\mathrm{X}$ & $\mathrm{X}$ & $\mathrm{X}$ & $\mathrm{X}$ \\
\hline $\mathrm{H}_{2}$ & & & $\mathrm{X}$ & $\mathrm{X}$ & \\
\hline
\end{tabular}

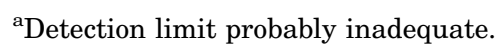


temperature entering the dry scrubber $\left(<120^{\circ} \mathrm{C}\right)$. As a consequence, concentration levels in the off-gas are to a large extent dictated by the amount of air used for cooling, and thus dilution, of the produced gases. In this chapter, gas compounds common to the aluminium reduction process are presented with an attempt to generalize the off-gas composition.

\section{Carbon Oxides}

Carbon oxides are the main gaseous products from reduction of alumina to aluminium. The difference in free energy for the formations is reflected by the fact that $\mathrm{CO}$ is more stable than $\mathrm{CO}_{2}$ at a process temperature of about $950^{\circ} \mathrm{C}: 46$

$$
\begin{array}{ll}
\frac{1}{2} \mathrm{Al}_{2} \mathrm{O}_{3}+\frac{3}{4} \mathrm{C}=\mathrm{Al}+\frac{3}{4} \mathrm{CO}_{2} \quad E^{\circ}=-1.18 \mathrm{~V} \\
\frac{1}{2} \mathrm{Al}_{2} \mathrm{O}_{3}+\frac{3}{2} \mathrm{C}=\mathrm{Al}+\frac{3}{2} \mathrm{CO} \quad E^{\circ}=-1.06 \mathrm{~V}
\end{array}
$$

The main anode reaction has been shown to be the formation of $\mathrm{CO}_{2}$, as the $\mathrm{CO}$-producing route is kinetically hindered. In the presence of solid carbon, $\mathrm{CO}_{2}$ reacts to form $\mathrm{CO}$ according to the Boudouard reaction. $\mathrm{CO}$ in the off-gas is mainly from air burn and $\mathrm{CO}_{2}$ burn due to insufficient coverage of the anode above the bath. The produced $\mathrm{CO}_{2}$ can also react with produced aluminium metal in a back reaction to form $\mathrm{CO}$ and alumina. Hence, the amount of $\mathrm{CO}$ depends on the operation of the reduction cell and anode coverage, e.g., a low interpolar distance will increase the back reaction and reduce the current efficiency (metal production).

The anode gas concentrations of evolved carbon oxides provide important information about the anode reactions and cell operation. Most of the published data on carbon oxide gas production are, however, reported from either laboratory-scale experiments or experiments where the anode gas is extracted from the cell attempting to avoid the aforementioned reactions of the carbon dioxide gas after being produced. ${ }^{47-49}$ Primary aluminium production off-gas composition, including both the $\mathrm{CO}$ and $\mathrm{CO}_{2}$ ratios, is, however, scarcely reported. Kimmerle ${ }^{48}$ reported numbers for $\mathrm{CO}_{2}$ and $\mathrm{CO}$ to be 14,500 and $1340 \mathrm{ppm}$, respectively. Aarhaug ${ }^{45}$ reported values of 7700 and $754 \mathrm{ppm}$ for $\mathrm{CO}_{2}$ and $\mathrm{CO}$, respectively. Fleer ${ }^{8}$ reported $\mathrm{CO}$ levels in the range of $500 \mathrm{ppm}$.

The dry scrubbing of off-gases has little impact on the carbon oxides as their absorbance on alumina is low. However, for the carbon consumption and environmental footprint, the ratio between $\mathrm{CO}_{2}$ and $\mathrm{CO}$ is important.

\section{Sulfurous Gas Species}

Cokes used in anodes in the reduction of alumina typically contain between 0.7 wt. $\%$ and 3.5 wt. $\%$ sulfur ${ }^{50}$ with normal levels close to $2 \%$. Most of the sulfur originates from the anodes; however, due to some adsorption on the primary alumina in the dry scrubber, which is released during addition of the secondary alumina to the bath, a significant amount of $\mathrm{SO}_{2}$ in the off-gas can be traced back to this cycle. Only a small contribution to the sulfur inventory is assumed to originate from the primary alumina. ${ }^{51}$ In addition to the emissions of fluorides, the sulfur emissions from the process are an environmental issue.

Although $\mathrm{SO}_{2}$ is the main sulfurous compound emitted from aluminium cells, the sulfur mass balance needs to take several other species into account. Extraction of unreacted anode gas has shown that COS is the main sulfur gas species formed during the reduction of alumina. An electrochemical reaction pathway has been proposed by Dorreen et al.: ${ }^{52}$

$$
\begin{gathered}
\mathrm{Al}_{2} \mathrm{O}_{3}+3 \mathrm{C}+3 \mathrm{~S}=3 \mathrm{COS}+2 \mathrm{Al} \\
E^{\circ}\left(970^{\circ} \mathrm{C}\right)=-1.04 \mathrm{~V}
\end{gathered}
$$

Equilibrium constants for the following reactions also suggests that $\mathrm{COS}$ can be formed by chemical reaction: ${ }^{2}$

$$
\begin{gathered}
\mathrm{S}+\mathrm{CO}_{2}+\mathrm{C}=\mathrm{COS}+\mathrm{CO} \quad K\left(970^{\circ} \mathrm{C}\right)=444 \\
\mathrm{~S}+\mathrm{CO}=\mathrm{COS} \quad K\left(970^{\circ} \mathrm{C}\right)=4.57
\end{gathered}
$$

Thermodynamic calculations support that COS reacts in the presence of $\mathrm{O}_{2}:{ }^{53}$

$$
\mathrm{COS}+\frac{3}{2} \mathrm{O}_{2}=\mathrm{CO}_{2}+\mathrm{SO}_{2} \quad K\left(970^{\circ} \mathrm{C}\right)=7.2 \cdot 10^{18}
$$

This equilibrium is shifted further to the right at lower temperatures: $K\left(120^{\circ} \mathrm{C}\right)=6.3 \times 10^{68}$, suggesting that COS should not be stable in the off-gas at temperatures between $0^{\circ} \mathrm{C}$ and $1000^{\circ} \mathrm{C}$. It is plausible that the reaction kinetics of COS with air is impaired at lower temperatures.

With an anode gas consisting mainly of $\mathrm{CO}_{2}$, reaction of COS with $\mathrm{CO}_{2}$ was evaluated by Utne: ${ }^{24}$

$$
\mathrm{COS}+2 \mathrm{CO}_{2}=3 \mathrm{CO}+\mathrm{SO}_{2} \quad K\left(970^{\circ} \mathrm{C}\right)=7.8 \cdot 10^{-4}
$$

The equilibrium is shifted further to the left at lower temperatures, $K\left(120^{\circ} \mathrm{C}\right)=3.9 \times 10^{-31}, 53 \mathrm{sug}$ gesting that $\mathrm{COS}$ should be stable even at high $\mathrm{CO}_{2}$ concentrations. Ødegård, ${ }^{55}$ based on thermodynamic simulations with varying sulfur concentrations and temperatures, showed that the concentration distribution between $\mathrm{COS}$ and $\mathrm{SO}_{2}$ is a function of the $\mathrm{CO}_{2}$ to $\mathrm{CO}$ ratio in the gas, but at lower temperatures the predominant species is COS.

Most of the COS is converted to $\mathrm{SO}_{2}$ when the hot anode gas meets the air from the draught to cool the cell gases before entering the ducts. Although COS 
has a modest global warming potential (27 in a 100year perspective), its stability provides transportation of sulfur to the upper atmosphere. Its decomposition is known to produce sulphate aerosols that both reflect incoming sunlight and contribute to the depletion of ozone. ${ }^{56}$ As a consequence, COS is the most abundant sulfur-containing gas in the atmosphere.

Anode gas characterization involves extraction of the gases to a gas analyser. Analysis is often performed at a gas temperature between $50^{\circ} \mathrm{C}$ and $300^{\circ} \mathrm{C}$. The speciation in the gas may be affected by the cooling of the gas. Experimental data clearly show that COS is the dominating sulfurous gas species when oxidation is avoided. ${ }^{48,49,52,54,55}$ Although the gas species $\mathrm{H}_{2} \mathrm{~S}$ and $\mathrm{CS}_{2}$ are frequently reported in small amounts in the anode gas, it is only occasionally reported for duct gas measurements. Most likely the observed $\mathrm{CS}_{2}$ (and $\mathrm{H}_{2} \mathrm{~S}$ ) is a result of decomposition of COS at intermediate temperatures $\left(350-600^{\circ} \mathrm{C}\right) .{ }^{57}$ Sulfurous species in the off-gas are less frequently reported than the $\mathrm{CO}_{2} / \mathrm{CO}$ ratio. A summary of the reported data is found in Table $\mathrm{V}$.

Tveito ${ }^{58}$ also analysed $\mathrm{COS}$ and $\mathrm{H}_{2} \mathrm{~S}$ before and after the dry and wet scrubbers. The results indicate low scrubbing efficiencies for these gases.

The formation of sulfuric acid in the primary aluminium off-gas has generally not been a problem with respect to corrosion of duct materials. The thermodynamics of possible formation mechanisms for $\mathrm{H}_{2} \mathrm{SO}_{4}$ is illustrated in Fig. 2, where data from Okkes and Bagder have been used. ${ }^{59}$

$\mathrm{SO}_{3}$ formation is generally formed by oxidation of $\mathrm{SO}_{2}$. The conversion efficiency is not well understood, and values between $1 \%$ to $5 \%$ are often assumed. ${ }^{60}$ In sulfuric acid production, the conversion of $\mathrm{SO}_{2}$ to $\mathrm{SO}_{3}$ is accelerated by catalytic conversion at temperatures in the range of 350 $400^{\circ} \mathrm{C}$. The observed variations in the amount of $\mathrm{SO}_{3}$ formed may be an effect of variations in metal impurities in the anodes, ${ }^{61}$ as these are frequently observed as particulates in the off-gas, e.g., $\mathrm{Fe}, \mathrm{Ni}$ and $\mathrm{V}$ compounds. $\mathrm{SO}_{3}$ is very hygroscopic and, once formed, it will react stoichiometrically with humidity to form sulfuric acid at temperatures below $400^{\circ} \mathrm{C}$.
In future design of aluminium smelters, the option to recover heat from the duct gas is inevitable. To optimise heat exchanger efficiency, a hotter and more concentrated off-gas is required. With increased concentrations of $\mathrm{SO}_{2}$, the condensation of sulfuric acid may occur at the cold surfaces of a heat exchanger. Assessment of the acid dew point is often done by open path spectroscopy. Aarhaug ${ }^{45}$ applied FTIR spectroscopy across an industrial-scale reduction cell to detect $\mathrm{SO}_{3}$ and $\mathrm{H}_{2} \mathrm{SO}_{4}$. An acid dew point value in the range 40$80^{\circ} \mathrm{C}$ has often been assumed for aluminium production. By using equations that correlate the acid dew point with the $\mathrm{SO}_{3}$ concentration, ${ }^{59,62}$ an estimate was calculated using the relevant humidity and fan draught parameters. Even though the sensitivity of the FTIR spectrometer was assumed sufficient, the only sulfurous species detected were $\mathrm{SO}_{2}$ and COS. It is speculated whether $\mathrm{SO}_{3}$ adsorption onto particulates can effectively lower the $\mathrm{SO}_{3}$ concentration in the gas phase. ${ }^{52}$ One likely option

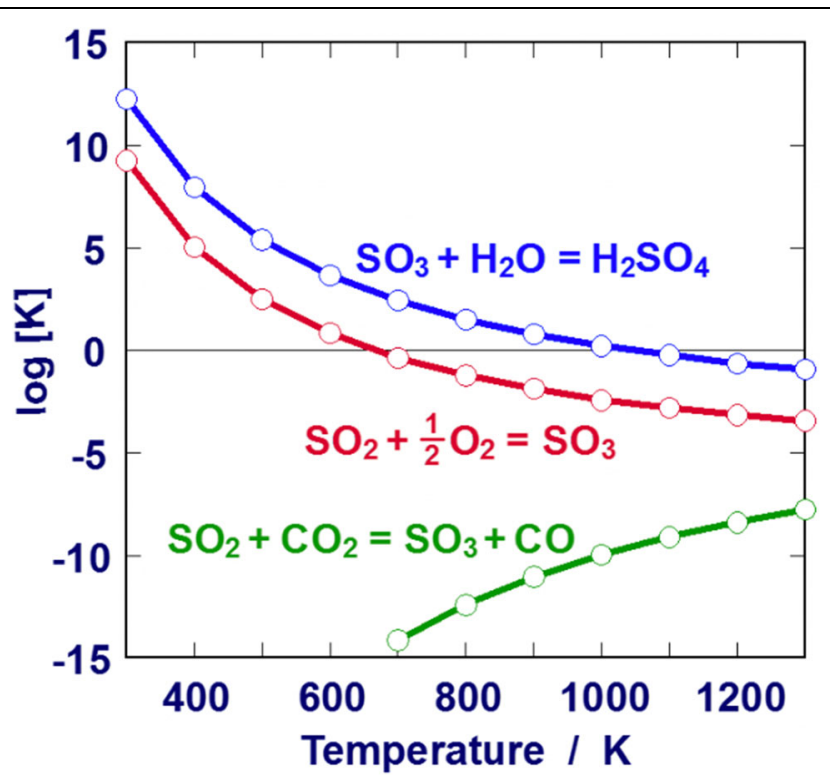

Fig. 2. Thermodynamics of the formation of sulfuric acid from $\mathrm{SO}_{2}$ (plotted from data in Ref. 59).

Table V. Duct off-gas compositions found in the literature. All numbers are in ppm mol

\begin{tabular}{|c|c|c|c|c|c|}
\hline Gas & Kimmerle $^{48}$ & Aarhaug $^{45}$ & Utne $^{54}$ & Utne $^{54}$ & Tveito $^{58}$ \\
\hline & GC-MS & FTIR & GC-FPD & GC-FPD & GC \\
\hline & Prebake & Prebake & Prebake & Söderberg & Prebake \\
\hline $\mathrm{SO}_{2}$ & 135 & 67 & 44 & 284 & 63 \\
\hline COS & 6.4 & 6.8 & 16 & 11 & 2.6 \\
\hline $\mathrm{CS}_{2}$ & 0.13 & & & & 0.69 \\
\hline $\mathrm{H}_{2} \mathrm{~S}$ & & & & & 1.5 \\
\hline $\mathrm{CO}_{2}$ & 12,050 & 7700 & & & \\
\hline $\mathrm{CO}$ & 1330 & 755 & & & \\
\hline
\end{tabular}


is that $\mathrm{SO}_{2}$ is adsorbed on particulates where it is converted to $\mathrm{SO}_{3}$, which reacts to sulphates. The observation of sulphates in the particulates from the off-gas $^{8,9}$ suggests an interaction between gaseous sulfur species and the particulates.

\section{Fluorides}

The off-gas from primary aluminium contains fluorides in both gaseous and particulate form. Due to the strong environmental impact of fluoride emissions, dry scrubbing technologies are universally applied. Today's dry scrubbers operate with recovery of fluorides $>99 \%$. Fluoride is considered a recovered valuable. By returning fluorides to the electrolyte, less aluminium fluoride needs to be added.

Hydrogen fluoride is the most abundant fluoride gas species in the off-gas. It is formed by reaction with fluorides in the bath or vapour phase according to reactions: ${ }^{44,63}$

$$
\begin{aligned}
2 \mathrm{AlF}_{3}(\text { diss })+ & 3 \mathrm{H}_{2} \mathrm{O}(\text { g or diss }) \\
=6 \mathrm{HF}(\mathrm{g})+\mathrm{Al}_{2} \mathrm{O}_{3}(\text { diss }) & \\
3 \mathrm{NaAlF}_{4}(\mathrm{~g}, \mathrm{~s})+3 \mathrm{H}_{2} \mathrm{O}(\mathrm{g})= & 6 \mathrm{HF}(\mathrm{g})+\mathrm{Na}_{3} \mathrm{AlF}_{6}(\mathrm{~s}) \\
& +\mathrm{Al}_{2} \mathrm{O}_{3}(\mathrm{~s})
\end{aligned}
$$

$$
\begin{aligned}
& 3 \mathrm{Na}_{5} \mathrm{Al}_{3} \mathrm{~F}_{14}(\mathrm{~g}, \mathrm{~s})+6 \mathrm{H}_{2} \mathrm{O}(\mathrm{g}) \\
& \quad=12 \mathrm{HF}(\mathrm{g})+5 \mathrm{Na}_{3} \mathrm{AlF}_{6}(\mathrm{~s})+2 \mathrm{Al}_{2} \mathrm{O}_{3}(\mathrm{~s})
\end{aligned}
$$

Water is available from the humidity in air but also the structural hydroxy groups in the primary alumina. ${ }^{38,64}$ In addition, HF may form from the hydrogen content of the anode, where an electrolytic reaction has been proposed: ${ }^{63}$

$$
2 \mathrm{AlF}_{3}(\text { diss })+3 \mathrm{H}_{2}(\mathrm{~g})=6 \mathrm{HF}(\mathrm{g})+2 \mathrm{Al}(\mathrm{l})
$$

The vaporization of the electrolyte releases $\mathrm{NaAlF}_{4}$ to the off-gas. ${ }^{65}$ The stability of this species has been much discussed, and a disproportionation into solid chiolite and aluminium fluoride has been proposed. ${ }^{66}$ Nevertheless, the above hydrolysis reactions suggest that all the fluoride species, in either gaseous or condensed form, can react. $\mathrm{NaAlF}_{4}$ has been reported in the condensed phase by Gaertner. ${ }^{9}$

It has been established that gaseous fluoride species comprise approximately 50\% of the total fluoride content in the off-gas. ${ }^{67,68}$ Several factors influence this ratio, crust integrity being one of the factors for evaporation of bath. Interestingly, seasonal changes in this ratio occur: higher air humidity levels in summer appear to increase hydrolysis, thus increasing the ratio of $\mathrm{HF}$ to particulate fluorides. ${ }^{63}$

As dry scrubbing technologies have become more than $99 \%$ efficient, the main source of fluoride emissions is now fugitive. ${ }^{69}$ Two gaseous fluorinecontaining species that, however, do pass through the dry (and wet) scrubbers are tetrafluoromethane
$\left(\mathrm{CF}_{4}\right)$ and hexafluoroethane $\left(\mathrm{C}_{2} \mathrm{~F}_{6}\right)$. The formation of fluorocarbons in primary aluminium production occurs at the anode when the local consumption of alumina becomes higher than the supply, reducing the local concentration of alumina to allow competitive anode reactions. For a constant current operation with anodes interconnected, the PFC formation on individual anodes can be seen as a shift in electrolytic resistance into anode overvoltage. Propagation of a local anode effect to a full cell anode effect can be seen as a result of higher current density at the anodes not depleted of alumina, which eventually becomes higher than the critical current density for $\mathrm{CF}_{4}$ and $\mathrm{C}_{2} \mathrm{~F}_{6}$ formation.

The most abundant PFC, tetrafluoromethane, is formed from the following reaction: ${ }^{52}$

$$
\begin{gathered}
4 \mathrm{Na}_{3} \mathrm{AlF}_{6}+3 \mathrm{C}=12 \mathrm{NaF}+4 \mathrm{Al}+3 \mathrm{CF}_{4} \\
E^{\circ}\left(970^{\circ} \mathrm{C}\right)=-2.54 \mathrm{~V}
\end{gathered}
$$

And similarly, hexafluoroethane:

$$
\begin{gathered}
2 \mathrm{Na}_{3} \mathrm{AlF}_{6}+2 \mathrm{C}=6 \mathrm{NaF}+2 \mathrm{Al}+\mathrm{C}_{2} \mathrm{~F}_{6} \\
E^{\circ}\left(970^{\circ} \mathrm{C}\right)=-2.78 \mathrm{~V}
\end{gathered}
$$

Although their contribution to the fluorine inventory is modest, their environmental impact is large with global warming potentials (GWP) in a 100-year perspective of 7390 and 12,200 for $\mathrm{CF}_{4}$ and $\mathrm{C}_{2} \mathrm{~F}_{6}$, respectively. ${ }^{70}$

Theoretically, an intermediate may be formed at lower voltages:

$$
\begin{gathered}
2 \mathrm{Na}_{3} \mathrm{AlF}_{6}+\mathrm{Al}_{2} \mathrm{O}_{3}+3 \mathrm{C}=6 \mathrm{NaF}+2 \mathrm{Al}+3 \mathrm{COF}_{2} \\
E^{\circ}\left(970^{\circ} \mathrm{C}\right)=-1.86 \mathrm{~V}
\end{gathered}
$$

While formation of $\mathrm{COF}_{2}$ is favourable thermodynamically, this species has only been reported once in laboratory-scale experiments with inert gas. ${ }^{52} \mathrm{An}$ attempt to reproduce this experiment was not successful. ${ }^{71}$ It has been suggested that $\mathrm{COF}_{2}$ is unstable and will either react with carbon to form $\mathrm{PFC}^{52}$ or self-disproportionate to form $\mathrm{CF}_{4}$ and $\mathrm{CO}_{2}$. Evidence of $\mathrm{CF}_{4}$ formation at low voltages may support an intermediate formation of $\mathrm{COF}_{2}$ followed by decomposition into $\mathrm{CF}_{4}{ }^{43,71}$ In industrial-scale electrolysis, $\mathrm{COF}_{2}$ is believed to decompose into $\mathrm{HF}$ and $\mathrm{CO}_{2}$ and is thus not present in the duct. In a beam-through cell experiment with open-path spectroscopy, only traces of $\mathrm{COF}_{2}$ have been identified. ${ }^{45}$

Historically, high PFC emissions were experienced during the start-up of electrolysis cells. Today, start-up protocols are aiming at minimizing the PFC emissions by means of proper pre-heating of the cells. ${ }^{72,73}$

\section{SUMMARY}

Several efforts have been made to relate raw gas composition and cell emissions to operational parameters. The present article presents a general 
overview; however, many factors are still uncertain and some may even be speculative. For instance, a good overview of secondary reactions and dilution variations by draught is still not well documented. Although the impurities in the raw materials are well documented, a good material balance or material flow during operation is lacking for many elements. Hence, the reported data are insufficient for performing a proper mass balance of the gas composition. As improved and more affordable state-of-the-art techniques for gas characterization have emerged, the ability to better relate observations to process conditions is promising. This may be even more important as the industry develops more energy-efficient reduction technology, e.g., by reducing the amount of draught used for cooling in combination with energy recovery from the raw gas. To be able to incorporate technology changes of this type, more detailed knowledge about the off-gas composition is required as limiting factors such as scale formation and acid dew points must be considered.

\section{ACKNOWLEDGEMENTS}

Funding was provided by Norges Forskningsråd (237738).

\section{OPEN ACCESS}

This article is distributed under the terms of the Creative Commons Attribution 4.0 International License (http://creativecommons.org/licenses/by/4.0/), which permits unrestricted use, distribution, and reproduction in any medium, provided you give appropriate credit to the original author(s) and the source, provide a link to the Creative Commons license, and indicate if changes were made.

\section{REFERENCES}

1. W.D. Lamb, Light Met. 1979, 889 (1979).

2. N. Tjahyono, Y. Gao, D. Wong, W. Zhang, and M.P. Taylor, Light Met. 2011, 301 (2011).

3. A.V. Mikhonin, N.R. Dando, and M. Gershenzon, Light Met. 2013, 905 (2013).

4. S.O. Strømmen, E. Bjørnstad, and G. Wedde, Light Met. 2000, 351 (2000).

5. S.J. Lindsay, N.R. Dando, and S. Broek, Light Met. 2017, 487 (2017).

6. N.R. Dando and S.J. Lindsay, Light Met. 2016, 527 (2016).

7. M.B. Mitchell, V.N. Sheinker, and M.G. White, J. Phys. Chem. 100, 7550 (1996).

8. M. Fleer, O.-A. Lorentsen, W. Harvey, H. Palsson, and G. Saevarsdottir, Light Met. 2010, 243 (2010).

9. H. Gaertner, Ph.D. dissertation, Norwegian University of Science and Technology (2013).

10. D.S. Wong, N.I. Tjahyono, and M.M. Hyland, Light Met. 2014, 553 (2014).

11. H. Kvande and P.A. Drabløs, J. Occup. Environ. Med. 56, S23 (2014).

12. A. Sørhuus and S. Ose, Light Met. 2017, 495 (2017).

13. A. Sørhuus, S. Ose, and E. Holmefjord, Light Met. 2018, 655 (2018).

14. A. Sørhuus, G. Wedde, K. Rye, and G. Nyland, Light Met. 2010, 249 (2010).

15. S.J. Lindsay, Light Met. 2013, 5 (2013).

16. W. Boenigk, C. Boltersdorf, C. Kuhnt, J. Stiegert, L. Edwards, and M. Lubin, Light Met. 2015, 1033 (2015).
17. S. Gao, C. Bao, B. Xia, R. Lin, J. Woo, G. Lang, and E. Cutshall, Light Met. 2014, 1105 (2014).

18. A. Sarkar, D. Kocaefe, D. Bhattacharyay, B. Morais, and C.L. Lagacé, Light Met. 2014, 1099 (2014).

19. K. Neyrey, L. Edwards, and J. Marino, Light Met. 2013, 1051 (2013).

20. S. Birghila, I.C. Popovici, and A. Dumitru, Rom. J. Phys. 56, 976 (2011).

21. B. Monsen, A.P. Ratvik, and L.P. Lossius, Light Met. 2010, 929 (2010).

22. L.C. Edwards, 11th AASTC 2014, Paper 08Key2 (2014).

23. L.C. Edwards, 10th AASTC 2011, Paper $2 a 1$ (2011).

24. K. Khaji and M. Al Qassemi, Metals 2016, 128 (2016).

25. N.R. Dando, Light Met. 2005, 133 (2005).

26. L.P. Lossius and H.A. Øye, JOM 43, 41 (1991).

27. S. Kalyavina, A.P. Ratvik, and T. Aarhaug, Light Met. 2013, 195 (2013).

28. H. Gaertner, A.P. Ratvik, and T.A. Aarhaug, Light Met. 2013, 769 (2013).

29. J. Thonstad, P. Fellner, G.M. Haarberg, J. Híveš, H. Kvande, and $\AA$. Sterten, Aluminium Electrolysis: Fundamentals of the Hall-Héroult Process (Düsseldorf: Aluminium-Verlag, 2001) (Ch. 10).

30. S.J. Lindsay, 9th AASTC 2007 (2007), p. 05.

31. P. Homsi, 6th AASTC 1998 (1998), p. 73.

32. A. Suss, A. Senyuta, M. Kravchenya, A. Smirnov, and A. Panov, ICSOBA 2015, Paper AA16 (2015).

33. D.V. Finin, M.A. Kravchenya, T.D. Pecherskaya, and A.V. Panov, Aluminium of Siberia, Proceedings XII (2006).

34. M.L. Slaugenhaupt, J.N. Bruggeman, G.P. Tarcy, and N.R. Dando, Light Met. 2003, 199 (2003).

35. C. Sommerseth, K.S. Osen, T.A. Aarhaug, E. Skybakmoen, A. Solheim, C. Rosenkilde, and A.P. Ratvik, Light Met. 2011, 339 (2011).

36. M. Hyland, E. Patterson, and B. Welch, Light Met. 2004, 361 (2004).

37. C. Sommerseth, K. Sende Osen, C. Rosenkilde, A.M. Meyer, L.T. Kristiansen, and T.A. Aarhaug, Light Met. 2012, 827 (2012).

38. W.E. Haupin and H. Kvande, Light Met. 1993, 257 (1993).

39. L. Perander, Z. Zujovic, T. Kemp, M. Smith, and J.B. Metson, JOM 61, 33 (2009)

40. S. Wilkening, P. Reny, and B. Murphy, Light Met. 2005, 367 (2005).

41. T.A. Aarhaug and A.P. Ratvik, Report No. SINTEF F17251 (2010).

42. H. Gamble, D.R. Karecki, G.I. Mackay, and H. Schiff, Light Met. 2003, 215 (2003).

43. H. Asheim, T.A. Aarhaug, A. Ferber, O.S. Kjos, and G.M. Haarberg, Light Met. 2014, 535 (2014).

44. K.S. Osen, T.A. Aarhaug, A. Solheim, E. Skybakmoen, and C. Sommerseth, Light Met. 2011, 263 (2011).

45. T.A. Aarhaug, A. Ferber, O. Kjos, and H. Gaertner, Light Met. 2014, 647 (2014).

46. J. Thonstad, P. Fellner, G.M. Haarberg, J. Híves, H. Kvande, and A. Sterten, Aluminium Electrolysis-Fundamentals of the Hall-Héroult Process, 3rd ed. (Düsseldorf: Aluminium Verlag, 2001).

47. J. Thonstad, J. Electrochem. Soc. 111, 959 (1964).

48. F.M. Kimmerle and L. Noël, Light Met. 1997, 153 (1997).

49. T.A. Aarhaug, O.S. Kjos, H. Gudbrandsen, A. Ferber, and A.P. Ratvik, Light Met. 2016, 533 (2016).

50. M. Ambrova, P. Fellner, J. Gabkova, and A. Sykorova, Chem. Pap. 59, 235 (2005).

51. J. Thonstad, I. Utne, K.A. Paulsen, and G. Svendsen, 6th AASTC 1998 (1998), p. 369.

52. M.M.R. Dorreen, D.L. Chin, J.K.C. Lee, M.M. Hyland, and B.J. Welch, Light Met. 1998, 311 (1998).

53. A. Roine, T. Kotiranta, H. Eerola, and P. Lamberg, HSC Chemistry 7.1 (Espoo: Outotec, 2011).

54. I. Utne, K.A. Paulsen, and J. Thonstad, Light Met. 1998, 293 (1998).

55. R. Ødegård, S. Rønning, Å. Sterten, and J. Thonstad, Light Met. 1985, 661 (1985). 
56. J. Dippell and W. Jaeshke, J. Atmos. Chem. 25, 251 (1996).

57. K. Karan, A.K. Mehrotra, and L.A. Behie, Chem. Eng. Commun. 192, 370 (2005).

58. K. Tveito, J. Tonheim, K.A. Paulsen, and J. Thonstad, Presented at the 40th Annual Conference of Metallurgists of CIM, Torono, 2001 (unpublished).

59. A.G. Okkes and B.V. Badger, Hydrocarb. Process. 66, 53 (1987).

60. K.B. Schnelle and C.A. Brown, Air Pollution Control Technology Handbook (London: CRC Press, 2002).

61. L.P. Belo, L.K. Elliot, R.J. Stanger, R. Spörl, K.V. Shah, J. Maier, and T.F. Wall, Energy Fuels 28, 7243 (2014).

62. F.H. Verkhoff and J.T. Banchero, Chem. Eng. Prog. 70, 71 (1974).

63. M.M. Hyland, B.J. Welch, and J.B. Metson, Light Met. 2000, 333 (2000).

64. W.E. Wahnsiedler, R.S. Danchik, W.E. Haupin, D.L. Brackenstose, and J.W. Colpitts, Light Met. 1978, 407 (1978).
65. H. Kvande, Dr. Techn. Dissertation, NTH (1979).

66. O. Bjørseth, O. Herstad, and J.L. Holm, Acta Chem. Scand. A 40, 566 (1986).

67. K. Grjotheim, H. Kvande, K. Motzfeldt, and B. Welch, Can. Metall. Q. 11, 585 (1972).

68. P. Jones and E. Keul, Light Met. 1991, 509 (1991).

69. E. Sum, 6th AASTC 1998 (1998), p. 667.

70. IPCC Fifth Assessment Report, edited by R.K. Pachauri and L.A. Meyer (2014).

71. O.S. Kjos, T.A. Aarhaug, E. Skybakmoen, and A. Solheim, Light Met. 2012, 623 (2012).

72. O.-A. Lorentsen, and K.A. Rye, Light Met. 2008, 1001 (2008).

73. K.A. Rye, Light Met. 2008, 1007 (2008).

Publisher's Note Springer Nature remains neutral with regard to jurisdictional claims in published maps and institutional affiliations. 